September 2018

APEC RR18-08

\title{
Reclaimed Water and Food Production: Cautionary Tales from Consumer Research
}

Olesya M. Savchenko ${ }^{1}$, Maik Kecinski ${ }^{2}$ Tongzhe $\mathbf{L i}^{3}$ and Kent D. Messer ${ }^{1}$

${ }^{1}$ Department of Applied Economics and Statistics, University of Delaware

2Department of Resource Economics and Environmental Sociology, University of Alberta ${ }^{3}$ Department of Economics, University of Windsor

\section{APPLIED}

ECONOMICS
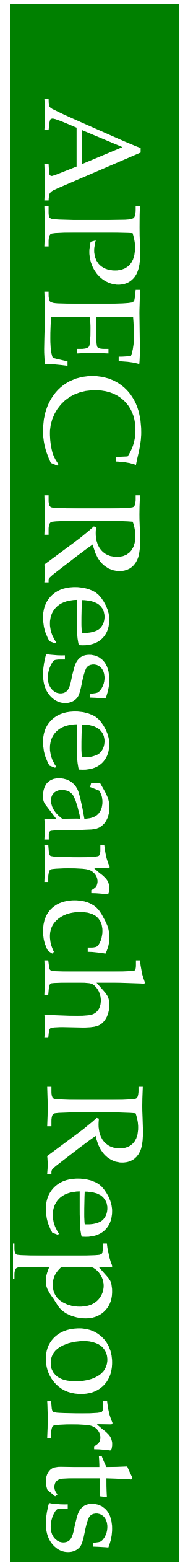


\section{ABSTRACT \\ Reclaimed Water and Food Production: Cautionary Tales from Consumer Research}

Keywords: Water reuse, reclaimed water, consumer behavior, food labeling

Reclaimed water has been identified as a viable and cost-effective solution to water shortages impacting agricultural production. However, lack of consumer acceptance for foods irrigated with reclaimed water remains one of the greatest hurdles for widespread farm-level adoption. Using survey data from 540 adults in the mid-Atlantic region of the U.S., this paper examines consumer preferences for six sources of reclaimed irrigation water and identifies statistically significant relationships between consumers' demographic characteristics and their preferences for each type of reclaimed water. Key findings suggest that consumers prefer rain water to all other sources of reclaimed water. Women are less likely than men to prefer reclaimed irrigation water sources and are particularly concerned about the use of black and brackish water.

Consumers who had heard about reclaimed water before are more likely to accept its use. Drawing on evidence from survey and experimental research, this paper also identifies disgust, neophobia and health concerns as the key issues that lead consumers to accept or reject foods produced with reclaimed water. Finally, we identify avenues for future research into public acceptance of reclaimed water based on our analysis and evidence from prior research.

\section{ACKNOLWEDGMENTS}

Funding support for this research was provided by the USDA National Institute for Food and Agriculture (grant number: 20166800725064), the USDA Economic Research Service, and the Center for Behavioral and Experimental Agri-Environmental Research (CBEAR). The authors acknowledge the support of James Geisler, Julia Parker, Francesca Piccone, Kaitlynn Ritchie, Maddi Valinski, and Huidong Xu for their assistance administering the field experiment.

For Additional information on this research on this course, contact:

\section{Kent Messer}

Department of Applied Economics and Statistics

226 Townsend Hall, Newark, DE 19716

messer@udel.edu 302-831-1316

\section{Suggested Citation for APEC Research Reports}

Savchenko, O.M., Kecinski, M., Li, T., and Messer, K.D. "Reclaimed Water and Food Production: Cautionary Tales from Consumer Research” Applied Economics and Statistics Research Report, University of Delaware, RR18-08. 


\section{Introduction}

Water scarcity is among the most critical challenges facing the world today. More than four billion people worldwide experience severe water shortages at least one month out of a year and half a billion people live under conditions of severe water scarcity year round (Mekonnen and Hoekstra, 2016). Demand for water will continue to rise due to increasing population, economic development, and urbanization while existing freshwater supplies will dwindle because of overuse and climate change. To address these challenges, alternative sources of water need to be developed worldwide.

Reclaimed water generated by treating wastewater of various types has been identified as a potential cost-effective, reliable and safe alternative to traditional sources of water such as rivers, lakes and aquifers (Chen et al., 2013). It is particularly well-suited for agricultural uses as it can be produced consistently and in large volumes. Currently, the agricultural sector consumes more than $70 \%$ of the world's freshwater resources (United Nations World Water Assessment Programme, 2016), and that figure is expected to increase dramatically as agricultural output worldwide is predicted to double by 2050 (World Bank, 2014). Furthermore, more than 50\% of the world's irrigated crop land is located in areas of extremely high water stress (World Resources Institute, 2013). Therefore, effective irrigation management and the development of reclaimed water sources are needed not only to ensure sufficient food production for the world's expanding population but also to mitigate water stress worldwide.

In response to water shortages and growing agricultural water demands, countries such as Israel, Singapore, and Australia have adopted water reclamation programs. Israel reuses $87 \%$ of its treated wastewater for agriculture (Marin et al., 2017). Approximately 40\% of Singapore’s total agricultural water needs are met through reclamation (PUB, Singapore's National Water 
Agency, 2018), and Australia has been steadily increasing its use of reclaimed water for agriculture and currently reuses $11.5 \%$ of the wastewater generated in the country (Seshadri et al., 2015). In the U.S., which produces 32 billion gallons of municipal effluent each day (National Research Council, 2012), however, water reclamation has been modest. Only about 8\% of that wastewater is reclaimed (Environmental Protection Agency, 2012) and about 29\% of the water that is reclaimed is used for agriculture (McNabb, 2017). Despite advances in wastewater treatment technologies, farm-level adoption in the U.S. and other countries hinges on consumer acceptance of products that have come into contact with reclaimed water - a substantial hurdle for widespread adoption (Hummer and Eden, 2016).

Consumers' responses to the use of reclaimed water are complex. A number of studies have examined various dimensions and drivers of acceptance of reclaimed water (e.g., Po et al., 2003; Po et al., 2005; Dolnicar et al., 2011; Rock et al., 2012; Hurlimann and Dolnicar, 2016; Kecinski and Messer, 2018a, see Fielding et al. 2018 for a review of survey results). A few other studies have used experimental economics approaches to gain insight into demand for food products irrigated with reclaimed water (Li et al., 2018; Savchenko 2018a). Economic field experiments allow researchers to study consumer behavior by placing them in non-hypothetical active market settings in which they exchange real money for real goods, thus revealing true preferences (Lusk and Shogren, 2007). As a result, such studies can produce estimates of consumer demand for foods irrigated with reclaimed water and compare these results to conventionally produced foods.

Several studies have also explored the links between public acceptance of reclaimed water and various demographic characteristics, but they have produced contradictory results. For example, McKay and Hurlimann (2003) and Menegaki et al. (2007) found that older individuals 
may be more concerned about reclaimed water compared to younger ones. Dolnicar and Schäfer (2009), on the other hand, showed that older consumers were more receptive than younger consumers and Po et al. (2005) reported no association between age and respondents' willingness to consume produce irrigated with reclaimed water. Similarly, studies of links between education level and acceptance of reclaimed water have produced mixed results. Rock et al. (2012) found that education had a positive effect since relatively educated respondents were more receptive to scientific information concerning the safety of reclaimed water while Hui and Cain (2017) documented no significant effect associated with education level. One factor that consistently had a negative impact on the acceptance of reclaimed water is the presence of children in a household. Menegaki et al. (2007) found that families with children were less likely to visit parks watered with reclaimed water, and Savchenko et al. (2018a) found that households that included children were less likely to pay for fresh food, particularly when it was produced with reclaimed water. In another study, however, Savchenko et al. (2018b) found that neither gender, education, nor children present in the home had significant impacts on consumer behavior. Therefore, further analyses of the impact of consumers' socio-economic characteristics on their preferences about using reclaimed irrigation water will offer new insights and contribute to this body of literature - this includes potentially heterogeneous responses to different sources of reclaimed irrigation water (e.g. black, brackish, gray, and storm water).

In this paper, we analyze survey data from 540 adults collected in the U.S. mid-Atlantic region. Specifically, we examine consumers' stated preferences for six sources of reclaimed irrigation water: storm water, rain water, black water, brackish water, industrial water and gray water. Our analysis identifies statistically significant relationships between consumers’ demographic characteristics and their preferences for each type of reclaimed water. Additionally, 
we draw on evidence from survey and experimental research to identify three key issues that lead consumers to accept or rejection of foods produced with reclaimed water: (1) Neophobia, (2) Disgust, and (3) Health Concerns. We also review the experimental economics literature and report on findings that provide further insight into consumer demand for foods produced with reclaimed water. We demonstrate how consumer perceptions for foods produced with reclaimed water may be undermined by food companies that use labeling that can stigmatize new technologies - thus, creating additional hurdles for successful implementation of sustainable and cost-effective reclaimed water irrigation. We close by identifying avenues for future research that may increase public acceptance of reclaimed water based on our own analysis and evidence from prior research.

\section{Consumer Preferences for Six Sources of Reclaimed Irrigation Water}

\section{Recruitment and Survey Design}

The survey collected data on socio-demographic characteristics, environmental attitudes, and shopping behaviors from 540 adults from the mid-Atlantic region of the U.S. ${ }^{1}$ We used convenience sampling, randomly recruiting participants at a large annual community event and a local farmers' market. ${ }^{2}$ Individuals who agreed to participate were provided with a tablet computer and were asked to complete a survey consisting of 18 questions presented on the screen (see Appendix A for the complete survey). The survey generally required about 15 minutes to complete and no communication was allowed amongst participants to ensure that their responses represented their individual preferences.

\footnotetext{
${ }^{1}$ The initial sample included 770 respondents. Ten participants' observations were excluded because of missing data regarding their income, education level, and age. And to ensure that our sample included only adults, we excluded 220 respondents who were younger than 22 and who had identified themselves as students.

${ }^{2}$ The survey was conducted as part of two field experiments designed to understand consumer responses to foods irrigated with reclaimed water. For a description of the experimental designs and procedures for those experiments, see Savchenko et al. (2018a,b).
} 
In terms of socio-demographic characteristics, participants were asked to record their age, gender, employment status, income category, education level, political affiliation, and whether children were present in their households. The questions about shopping behaviors asked whether they were the primary shopper in the household, the percentage of their overall food consumption that was organic, whether they grew their own food, and whether they preferred to purchase locally produced foods. In the last section of the survey, they were asked about their preferences for different types of drinking water (bottled, filtered tap, tap, other), reclaimed irrigation water (gray, black, brackish, industrial, rain, and storm water; which were all defined for them in the survey), and their degree of concerns about the availability of water at several spatial and temporal scales. Responses were reported on a Likert scale ranging from 1 for "Dislike” and 9 for "Like” for questions related to preferences for reclaimed irrigation water. Questions related to water availability concerns were also reported on a Likert scale ranging from 1 for "Not important" to 9 for "Very important". The following definitions for the different sources of reclaimed water were presented to the participants:

\section{Gray water}

It generally refers to the wastewater generated from household uses like bathing and washing clothes (EPA 2016a).

\section{Black water}

Also described as Brown Water. It generally refers to the wastewater generated from toilets (EPA, 2016b).

\section{Brackish water}

It is typically defined as distastefully salty but less saline than seawater (between 1,000 to $10,000 \mathrm{ppm}$ [parts per million] in total dissolved solids [TDS]). In addition to certain surface water settings such as estuaries, brackish water can be found in aquifers (National Groundwater Association, 2017).

\section{Industrial water}

It generally means process and non-process wastewater from manufacturing, commercial, mining, and silvicultural (forestry) facilities or activities, including the runoff and leachate from areas that receive pollutants associated with industrial or commercial storage, handling 
or processing, and all other wastewater not otherwise defined as domestic wastewater (EPA, 2018a).

\section{Rainwater}

Generally, the term rain water refers to water coming from rooftops and other aboveground surfaces.

\section{Storm water}

Generally, the term stormwater refers to rainwater collected from non-roof surfaces, such as parking lots, hardscapes, and landscapes surrounding urban buildings (EPA, 2018b).

\section{Data Analysis and Results}

Table 1 summarizes the demographic and stated preferences profiles of the survey participants. About $60 \%$ of the sampled participants were women, most participants were relatively educated (had either a bachelor's or a graduate degree) and more than half of the participants households (52\%) had an income of $\$ 50,000$ or more per year. Children under the age of 18 were present in approximately $30 \%$ of the households. In terms of political affiliation, the majority of the participants described themselves as moderate (37\%) or liberal (37.1\%). More than half of all the participants preferred to purchase local food when possible (64.5\%), were primary shoppers in their households (72.5\%), and had heard about reclaimed water before participating in the study (68.4\%).

Table 2 reports mean and median responses to the questions related to participants' preferences concerning water using various temporal and spatial scales. The results show that consumers are generally concerned about current water issues and the availability of water in the future. More than $70 \%$ of the participants expressed concerns about water locally and at a state, national, and global level. Figure 1 provides mean preferences for different sources of reclaimed irrigation water and their 95\% confidence intervals. As can be seen from Table 2 and Figure 1, when asked about their preferences for different sources of reclaimed water ( "How do you feel 
about these different types of non-traditional waters for irrigation"), participants indicated that they most disliked black, brackish, and industrial water for irrigation; storm and rain water were the most acceptable sources.

We then examined participants' preferences for the different types of reclaimed irrigation water using a random-effects ordered logit model that included various stated survey responses as independent variables (see Appendix B for variable definitions). Participants indicated their preferences for different sources of reclaimed water on a Likert scale in which 1 represented "Dislike” and 9 represented "Like”. This ordered, categorical dependent variable for their preferences required use of an ordered logit model, in which specification of the random effects controlled for within-subject correlation. The results of the analysis are summarized in Table 3.

Compared to rain water, which was the baseline category, consumers were significantly less likely to prefer gray, brackish, industrial, storm, and black water - indicating that consumers may perceive rain water as the cleanest of the six types presented. A similar result was found in an experimental study of consumer preferences for different reclaimed water types by Ellis et al. (2017) who showed that U.S. consumers stigmatized grey water, black water and produced water, which was defined in the study as treated wastewater from oil and gas drilling operations. We also found that women were less likely than men to prefer reclaimed irrigation water sources. This finding is consistent with several prior studies that have also found that men are generally less hesitant about reclaimed water than women (Po et al., 2005; Dolnicar and Schäfer, 2009). Furthermore, consumers who had heard about reclaimed water previously were more likely to prefer reclaimed water sources. Prior studies have presented similar results, i.e. prior knowledge of reclaimed water have contributed to greater acceptance of reclaimed water (Dolnicar et al., 
2011; Pham et al., 2011) or higher likelihood of produce purchase that had been irrigated with reclaimed water (Ellis et al., 2017).

To explore potentially heterogeneous relationships between consumers’ preferences for each source of reclaimed irrigation water type and their demographic and behavioral characteristics, we analyzed each source of water in an ordered logit model presented in Table 4. We find that the positive statistically significant effect of prior knowledge (Heard) on consumers' preferences is mostly driven by gray water and rain water, but also by black water (Heard, 0.441, $p<0.02$ ) and storm water (Heard, 0.385, $p<0.02$ ).

Similar to several other studies that found significant relationship between higher levels of education and reclaimed water acceptance (Wester et al., 2015; Rock et al., 2012; Po et al., 2005), our results suggest that more-educated participants showed a stronger tendency than lesseducated participants to prefer rain water, while this relationship was statistically insignificant for other reclaimed irrigation water sources.

Our analysis also indicates that women's greater tendency to reject reclaimed water for irrigation than men comes primarily from their concern about use of black and brackish water. As expected, individuals who grow their own food are more likely to favor storm and rain water for recycling and to dislike use of industrial water. This finding is intuitive since many people who grow their own food use rain water on their crops.

We also found that a liberal political affiliation is positively and statically significantly associated (Liberal, $0.864, p<0.02$ ) with a preference for use of gray water for recycling. This is in contrast to Haddad et al. (2009) who found that individuals who were either highly liberal or highly conservative were less likely to drink reclaimed water. 
We also find that older consumers are more likely to prefer gray water than younger consumers, however, age is significantly negatively related to preference for storm water.

\section{Consumer Response to Foods Produced with Reclaimed Water}

\section{Where are We at Now?}

As evident from our analysis, consumers’ socio-demographic profiles can significantly affect their acceptance of different sources of reclaimed irrigation water. However, we also demonstrate that consumers are generally reluctant to accept other sources of reclaimed water compared to rain water. Our findings add to the literature that has documented public aversion to reclaimed water (Po et al., 2005; Toze, 2006; Hurlimann, 2007; Dolnicar and Schäfer, 2009; Dolnicar and Hurlimann, 2010; Rock et al., 2012; Lease et al., 2014; Hurlimann and Dolnicar, 2016). Studies have shown that the aversion associated with reclaimed water can extend to foods irrigated with it. Using a non-hypothetical experiment to elicit consumers’ WTP for fresh produce irrigated with reclaimed water, Savchenko et al. (2018a) showed that consumers were less willing to pay for strawberries, blueberries, spinach, and broccoli labeled as grown with reclaimed water than for the same foods labeled as grown with conventional water and with labels that did not specify the irrigation water used. Li et al. (2018), in a study of wine made from grapes irrigated with reclaimed water, found that providing information about the type of water used for irrigation generally reduced U.S. consumers’ WTP relatively to a no-label treatment and that the lowest WTP values were associated with wine from grapes irrigated with reclaimed water. Ellis et al. (2017) showed that consumers' demand for foods declined $87 \%$ in the U.S. and $20 \%$ in Israel when they were identified as having been irrigated with reclaimed water. The authors also found that the decrease in WTP depended on the type of water that was

reclaimed when considering gray, black, produced, effluent, and desalinated water. In all of these 
studies, consumers were presented with opportunities to purchase actual food products that had been produced using reclaimed irrigation water.

This decline in consumer demand for foods produced with reclaimed water shares similarities with the stigma associated with drinking reclaimed water, though perhaps it is not as strong. In economics terms, stigma is a negative reaction (to a product or service) that exceeds the actual risk associated with a good (Fischhoff, 2001). Numerous psychology studies have explored stigma in general (e.g., Fallon et al., 1984; Rozin et al, 1986; Rozin et al, 1995; Hejmadi et al., 2004) and a few economic studies have addressed its influence on consumers' decisions. Kecinski et al. (2017), for example, explored the economic impacts of stigma using experiments that collected data on participants' willingness to pay (WTP) to avoid drinking a glass of water "contaminated" with a dead sterilized cockroach and willingness to accept (WTA) payments for drinking the water. They found that stigma reduced consumers' willingness to drink the "contaminated" water despite the presence of financial incentives.

Stigma can be difficult to reduce or eliminate for goods that are ingested (Rozin, 2001). Therefore, studies have begun to explore ways to mitigate stigma associated with reclaimed water and foods produced with it. For example, Savchenko et al. (2018b) investigated processing as a potential way to reduce the stigma associated with produce irrigated with reclaimed water and found that use of reclaimed irrigation water did not affect consumers' WTP for processed foods. They suggested that processed foods are perceived as further removed from direct contact with the reclaimed water. Other studies addressed whether information can mitigate some of the stigma associated with reclaimed water and the types of information most likely to be successful. Fielding and Roiko (2014) found that providing positive information about how reclaimed water is treated to make it drinkable increased consumers' support and Simpson and Stratton (2011) 
demonstrated that exposing consumers to a lengthy online informational brochure about reclaimed water led to an increase in U.S. consumers' acceptance of it for potable uses. Furthermore, Hui and Cain (2017) found that providing information about an existing program for reclaimed potable water to survey respondents in California increased their support for use of reclaimed water in applications that did not involve direct contact, such as drinking, cooking, and bathing. In a field experiment on consumer response to fresh produce irrigated with reclaimed water, Savchenko et al. (2018a) found that the balanced, positive-plus-negative information about reclaimed water was more effective than the benefit information alone, confirming the results of several other studies about the effects of positive and negative information (Messer et al., 2011; Kajale and Becker, 2014; Price et al., 2015).

The studies presented above showed that consumers stigmatize reclaimed water and foods produced with it and have begun to identify how to destigmatize these products. However, little experimental research has been done to understand why consumers stigmatize these foods and which factors drive this response. Stigma is a powerful element in consumers' response to new technology (Gregory et al., 2001), therefore, understanding the various factors that induce stigma can help the food industry and policymakers to reduce or eliminate stigmatization of foods produced with reclaimed water.

\section{Drivers of Consumer Acceptance or Rejection of Foods Produced with Reclaimed Water}

We identified three overarching factors that can induce stigma and, therefore, may determine consumer acceptance or rejection of food produced with reclaimed water. These three key factors were determined based on evidence from existing survey and experimental research and the researchers' own experiences conducting field research on reclaimed water products that engaged well over a thousand participants. Figure 2 summarizes the interconnected and 
overlapping nature of (1) Disgust, (2) Neophobia and (3) Health Concerns in a Venn diagram. Below, we provide a review of the studies that support the importance and determining role these three factors play in accepting or rejecting reclaimed water and foods that have come into contact with it. Finally, using examples of how negative consumer attitudes have undermined other agricultural technologies, we provide some insights into marketing strategies that can avoid similar backlash to the use of reclaimed water in agriculture.

Disgust associated with reclaimed water has received considerable attention in the economic and policy literature (Po et al., 2003; Alhumoud et al., 2003; Menegaki et al., 2007; Lease et al., 2014; Kecinski and Messer, 2018a). Studies have argued that due to disgust reclaimed water may be most acceptable for uses that involve little human contact with the water itself, such as irrigating parks and lawns and washing clothes, and least acceptable when the water is used for drinking, cooking, and irrigating fresh produce (Po et al., 2005; Toze, 2006; Hurlimann, 2007; Dolnicar and Schäfer, 2009; Dolnicar and Hurlimann, 2010; Rock et al., 2012; Lease et al., 2014; Kecinski et al., 2016; Hurlimann and Dolnicar, 2016, Hui and Cain, 2017; Savchenko et al., 2018a). In a survey of consumers in Arizona, Rock et al. (2012) found that $67 \%$ of respondents were in favor of using reclaimed water to irrigate non-edible crops while only $28 \%$ favored it for vegetable crops. This aversion to reclaimed water is typically attributed to the "yuck factor"- - a psychological feeling of disgust associated with waste water, which contains sewage and other sources of contagion (Po et al., 2003; Haddad et al., 2009; Rozin et al., 2015, Kecinski et al., 2017). The disgust associated with treated reclaimed waste water, even when non-potable, attaches by the law of contagion: an item that comes in contact with a contaminated object is perceived as contaminated even after the contagion itself is removed and the item cleaned (Rozin and Fallon, 1987). Treatment that results in water that meets even the 
most stringent scientific standards of safety for drinking does not necessarily alleviate individuals’ powerful sense of disgust; “once in contact, always in contact” (Rozin, 2001).

Neophobia related to food is the fear of trying new and potentially risky foods. Little is known about the effects of neophobia on consumers' acceptance of foods produced using reclaimed water. However, studies of consumer acceptance of foods produced using other new technologies perceived as risky, such as genetic engineering and nanotechnology, have shown that "dread risk" (a level of risk that could be fatal) and unknown risks play important roles in consumers’ opposition to those foods (Slovic, 1987; Flynn et al., 2001; Townsend and Campbell, 2004; Finucane and Holup, 2005; Townsend, 2006) and that consumers' WTP for products that are genetically engineered is $23 \%$ to $28 \%$ less than their WTP for conventional food products (Lusk et al., 2014; Messer at al., 2017). A major challenge in addressing concerns about potential risks posed by reclaimed irrigation water is that risk aversion typically is based, at least in part, on individuals' emotional reactions and instinctual responses to anything that could cause harm. Consequently, scientific information about the true degree of risk, if any, posed by reclaimed water may not be able to assuage their concerns.

Another issue related to neophobia is the amount of control consumers see themselves as having over perceived risks associated with food (Messer et al., 2017). They could control their exposure to risk by choosing not to purchase or ingest foods perceived as risky. Alhakami and Slovic (1994) showed that consumers typically evaluate the risks and benefits of a food product simultaneously and that their opposition to technologies such as genetic engineering and use of reclaimed water for food may stem from a belief that such products put them at risk and primarily benefit the producer (Messer et al. 2015). 
Health concerns about foods irrigated with reclaimed water can also evoke consumer rejection. Several studies (Dillaway et al., 2011; Messer et al., 2017; Kecinski et al., 2018b) have found that, in general, consumers' demand for foods declines substantially in response to safety concerns and real or exaggerated perceived risks. Using data from experimental auctions, Hayes et al. (1995) found that consumers' WTP for foods declines as their perceptions of risks associated with food-borne illness intensify. Likewise, McFadden and Huffman (2017) demonstrated that individual WTP for potato chips and French fries dropped after consumers became aware that those foods could contain acrylamide, a potential carcinogen. Studies specific to acceptance of reclaimed water also showed that elevated health concern is a critical factor associated with lower acceptance of reclaimed water for potable and non-potable uses (Dolnicar and Hurlimann, 2010; Hurlimann and Dolnicar, 2016). Psychologically this rejection maybe exacerbated as ingestion through the mouth, which is generally thought of as one of the most body-sensitive parts (Rozin et al., 1995).

Consumers' health and safety concerns are often amplified by the media reporting on outbreaks of foodborne illnesses and other types of contamination. News coverage tends to address negative events far more often than the benefits of emerging food technologies such as reclaimed water (Swinnen et al., 2005; Messer et al., 2017). In fact, Schmidt et al. (2017) tested the effects of several specific information treatments about reclaimed water and sources of the information and found that a newspaper report had a stronger effect on consumer behavior than the same message cited as delivered by scientists, a government agency, and an environmental nonprofit organization. Media stories and references to reclaimed water as "toilet to tap" tend to exaggerate feelings related to disgust, neophobia and health concerns associated with reclaimed water, increasing consumers' concerns about its use (Po et al., 2003). Further, the behavioral 
sciences and psychology have established that people generally weigh negative information more heavily than positive information (Kahneman and Tversky, 1979) and a number of proposed reclaimed water projects have failed despite ample scientific evidence of their safety because of such “negative bias” (Friedler and Lahav, 2006; Uhlmann and Head, 2011).

Trust in food safety is also an important element in consumers' purchase. With much of the world's food supply provided by large corporations, consumers know little about how and where the food they buy was produced, creating an information asymmetry between producers and consumers (Nelson, 1970) and potentially a lack of trust among consumers. The results of studies that have explored trust and acceptance of reclaimed water have been mixed. Fielding et al. (2015) and Ross et al. (2014) found that trust in authorities (e.g., government agencies) was a predictor of accepting reclaimed water for potable and non-potable uses while Gibson and Burton (2014) found no significant association between acceptance and trust.

The information asymmetry between producers and consumers can be mitigated, to some extent, by providing information in labels attached to the products. Though food labels can communicate important information about production processes to consumers, they can also stigmatize foods despite scientific evidence that the technologically processed foods are safe (Messer et al., 2017). Numerous studies have documented consumers' negative perceptions of technologies such as genetic engineering, irradiation, and use of growth hormones and antibiotics (Kanter et al., 2009; Costanigro and Lusk 2014; Messer et al., 2015) and dramatic declines in WTP for foods associated with those processes via labeling (Hayes et al., 2002; Lusk et al., 2005). Intense opposition from consumers has led to foods produced without those technologies being labeled to promote the fact that they are "Non GMO" (genetically modified) or "rbSTfree” (a synthetic version of naturally occurring bovine somatotropin) in milk. Given the number 
of consumers who have expressed concerns about innovations and processing technologies, it is not surprising that U.S. producers have been reluctant to adopt reclaimed irrigation water.

Given the concerns expressed by consumers, producers that are already irrigating with reclaimed water have not displayed that information on labels, but some producers have begun to market their products using labels identifying them as irrigated with "fresh" or "pure well" water. However, this practice can stigmatize foods irrigated with reclaimed water and also conventionally irrigated foods. Kanter et al. (2009), for example, found that labeling milk as free of rbST resulted in a 33\% reduction in WTP for conventional type of milk compared with individuals who were not explored to rbST-free label prior to making milk purchase. Ellis et al. (2018) also found the names typically used to describe reclaimed water, such as Recycled, Reclaimed, Treated Wastewater, Nontraditional and Reused, are least preferred by consumers. However, if this water is branded using names such as Pure Water, Econ-Friendly Water or Advanced Purified Water, it increase consumers' favorability of reclaimed water because these names induce desirable water characteristics of reclaimed such as "pure”, "fresh” and "natural”

The results suggest that the common names for this water, such as Recycled, Reclaimed, Nontraditional, Treated Wastewater, and Reused, are the least appealing, as they all scored at the bottom. In contrast, names that invoke desirable characteristics of the water-Pure, EcoFriendly, and Advanced Purified, were viewed significantly more favorable than the others.

\section{Avenues for Future Research}

A substantial body of research has accumulated regarding consumers’ responses to use of reclaimed water in general and a few studies have recently emerged on foods produced using reclaimed water for irrigation, however, numerous questions remain. This review of prior studies 
that employed surveys and economic experiments, along with our analysis of consumer perceptions of various sources of reclaimed water, points to several avenues for future research.

First, although survey-based studies provide valuable insights into consumer responses, there is a need for additional experiment-based research into consumer behavior associated with reclaimed water. Experiments allow for creation of markets in which participants can exchange actual money for real food products that were irrigated with reclaimed water (no deception allowed), making it difficult for study participants to misrepresent their true valuations of the goods. Furthermore, experiments generally incorporate randomized designs that enable researchers to draw causal conclusions about the impact of various factors and treatments on consumer demand for a product. Furthermore, field experiments allow researchers to target particular populations of interest, decrease sample selection bias (Lusk and Fox, 2003), and collect data in more-natural settings (Harrison and List, 2004). As evident from our review, only a handful of studies to date have used experimental economics to understand consumer demand for foods irrigated with reclaimed water.

A second avenue needing exploring is strategies for reducing and eliminating consumers’ stigmatization of reclaimed water applications with particular focus on how to disentangle the determining factors of stigma such as disgust, neophobia and health concerns. The studies completed so far have pointed to processing of fresh foods to "stretch" the perceived distance between reclaimed water and the consumer and balanced informational treatments providing both positive and negative information as ways to mitigate some of the stigma. Experimental research has not addressed disgust, neophobia and health concerns that stigmatize foods produced with reclaimed water both individually and collectively. Additional research is needed in other areas that could potentially destigmatize reclaimed water, including (a) investigating 
why consumers stigmatize reclaimed water and the extent to which disgust, neophobia and health concerns drive consumers' lack of demand for foods produced with reclaimed water, (b) examining a greater variety of foods, (c) investigating the effects of additional types of information aimed at nudging consumers toward acceptance, (d) analyzing the long-term effectiveness of various messages and campaigns, (e) exploring how social priming and prominent public figures who can influence consumers and have access to the media can shape consumers' perspectives on using reclaimed water in agriculture, (f) investigating how positive framing and various terminologies used to describe uses of reclaimed water affect consumer responses, and (g) gaining insight into how a greater public need (such as the needs of socially and economically disadvantaged people) and public benefits (such as providing long-term sustainable solutions to water shortages) can increase the acceptance of reclaimed water.

Another fertile field of research is potentially heterogeneous responses to reclaimed water policies. Our survey results suggest that consumers' acceptance of reclaimed water is segmented with some demographic groups being more accepting than others. The impacts of social networks and peers should also be studied since certain consumer groups are more likely be early adopters of this water source innovation.

Almost no work has been done on adoption of reclaimed water practices from producers' perspectives. What strategies would promote adoption, what barriers are holding them back, and what information could assist them in effectively promoting reclaimed-water products? The classic assumption is that producers are profit-maximizers and choose technologies based on a monetary benefit-cost analysis. Additional studies of consumer valuations of such products and processes are essential for predicting producers' potential revenues and hence present a fruitful area to explore. In addition, producers' beliefs about the importance of water conservation and 
perceptions of risks associated with reclaimed water may be heterogeneous. These attitudinal factors can play an important role in producers' adoption decisions and are worth investigating.

Finally, the analysis in this paper provides insight into consumer characteristics that are associated with their preferences for various sources of reclaimed water. The results suggest that consumers favor storm runoff and rain for recycling and are hesitant to purchase agricultural products associated with reclaimed industrial and black water for irrigation. Future studies are needed to identify optimal applications in the minds of consumers for each type of reclaimed water. They might, for example, reject reclaimed industrial water for irrigating food crops but accept it for irrigating lawns.

\section{Conclusion}

The agricultural sector in the U.S. is facing a significant challenge as it seeks to satisfy its need for water while at the same time contributing to mitigation of water shortages. Alternative water supplies, such as reclaimed waste water, offer a viable, cost-effective, and sustainable solution to this challenge that has already proven effective in other countries. Despite the many benefits of reclaimed water, however, consumer opposition has limited its adoption, particularly for applications involving food crops.

In this paper, we analyze the impact of socio-demographic and behavioral characteristics on the preferences of 540 adults from the mid-Atlantic region of the U.S. for six sources of reclaimed irrigation water. We find that consumers generally have a clear preference for rain water over alternative sources of reclaimed irrigation water such as black, brackish, gray, industrial, and storm water. Overall, women object more than men to reclaimed waste water in general and to black and brackish water sources in particular. We also find that individuals who 
have heard about reclaimed water are significantly more likely to accept reclaimed irrigation water.

We then summarize existing literature regarding consumer responses to reclaimed water and to foods irrigated with it to identify key factors driving acceptance and rejection of reclaimed water for food production that include (1) Disgust, (2) Neophobia, (3) Health Concerns. Our analysis of newly collected survey data and review of the existing literature also identify numerous avenues for future research that will assist both producers and policymakers in efforts to encourage use of reclaimed water in agricultural production. 


\section{References}

Alhakami, A.S., Slovic, P., 1994. A Psychological Study of the Inverse Relationship Between Perceived Risk and Perceived Benefit. Risk Analysis 14, 1085-1096. https://doi.org/10.1111/j.1539-6924.1994.tb00080.x

Alhumoud, J.M., Behbehani, H.S., Abdullah, T.H., 2003. Wastewater Reuse Practices in Kuwait. The Environmentalist 23, 117-126. https://doi.org/10.1023/A:1024831503569

Chen, W., Lu, S., Jiao, W., Wang, M., Chang, A.C., 2013. Reclaimed water: A safe irrigation water source? Environmental Development 8, 74-83.

Costanigro, M., Lusk, J.L., 2014. The signaling effect of mandatory labels on genetically engineered food. Food Policy 49, 259-267. https://doi.org/10.1016/j.foodpol.2014.08.005

Dillaway, R., Messer, K.D., Bernard, J.C., Kaiser, H.M., 2011. Do Consumer Responses to Media Food Safety Information Last? Appl Econ Perspect Policy 33, 363-383. https://doi.org/10.1093/aepp/ppr019

Dolnicar, S., Hurlimann, A., 2010. Desalinated versus recycled water: what does the public think? Sustainability Science and Engineering 2, 375-388.

Dolnicar, S., Hurlimann, A., Grün, B., 2011. What affects public acceptance of recycled and desalinated water? Water Research 45, 933-943. https://doi.org/10.1016/j.watres.2010.09.030

Dolnicar, S., Schäfer, A.I., 2009. Desalinated versus recycled water: public perceptions and profiles of the accepters. Journal of Environmental Management 90, 888-900.

Ellis, S.F., Kecinski, M., Messer, K.D., Lipchin, C., 2017. Gaps in risk perceptions between the United States and Israel: Field experiments on various types of nontraditional water. Society of Risk Analysis Annual Meeting, Arlington, VA.

Ellis, S.F., Savchenko, O., Messer, K.D. 2018. What's in a name? Branding reclaimed water. Unpublished manuscript.

Environmental Protection Agency, 2012. Guidelines for Water Reuse. Accessed July 3, 2018 at https://nepis.epa.gov/Adobe/PDF/P100FS7K.pdf.

Environmental Protection Agency, 2016a. Greywater. Accessed July 5, 2017, at http://www.epa.sa.gov.au/environmental_info/water_quality/programs/grey_and_black_water_di scharge/grey_water.

Environmental Protection Agency, 2016b. Blackwater. Accessed July 5, 2017, at http://www.epa.sa.gov.au/environmental_info/water_quality/programs/grey_and_black_water_di scharge/black_water.

Environmental Protection Agency, 2018a. National Pollutant Discharge Elimination System (NPDES). Industrial Wastewater. Accessed July 3, 2017, at https://www.epa.gov/npdes/industrial-wastewater.

Environmental Protection Agency, 2018b. National Pollutant Discharge Elimination System (NPDES). NPDES Stormwater Program. Accessed July 3, 2017, at https://www.epa.gov/npdes/npdes-stormwater-program.

Fallon, A.E., Rozin, P., Pliner, P., 1984. The Child’s Conception of Food: The Development of Food Rejections with Special Reference to Disgust and Contamination Sensitivity. Child Development 55, 566-575. https://doi.org/10.2307/1129968

Fielding, K.S., Dolnicar, S., Schultz, T., 2018. Public acceptance of recycled water. International Journal of Water Resources Development 0, 1-36. https://doi.org/10.1080/07900627.2017.1419125

Fielding, K.S., Gardner, J., Leviston, Z., Price, J., 2015. Comparing Public Perceptions of Alternative Water Sources for Potable Use: The Case of Rainwater, Stormwater, Desalinated Water, and 
Recycled Water. Water Resour Manage 29, 4501-4518. https://doi.org/10.1007/s11269-0151072-1

Fielding, K.S., Roiko, A.H., 2014. Providing information promotes greater public support for potable recycled water. Water Research 61, 86-96. https://doi.org/10.1016/j.watres.2014.05.002

Finucane, M.L., Holup, J.L., 2005. Psychosocial and cultural factors affecting the perceived risk of genetically modified food: an overview of the literature. Social Science \& Medicine 60, 16031612. https://doi.org/10.1016/j.socscimed.2004.08.007

Fischhoff, B., 2001. Defining stigma. In Flynn, J., Kunreuther, J., Slovic, P.,Eds., Risk, media, and stigma, 361-368. Sterling, VA: Earthscan Publication Ltd.

Flynn J, Slovic P, Kunreuther H, Eds. 2001. Risk, media, and stigma: Understanding public challenges to modern science and technology. Sterling, VA: Earthscan Publication Ltd.

Friedler, E., Lahav, O., 2006. Centralized urban wastewater reuse: What is the public attitude? Water Science and Technology 54, 423-430.

Gibson, F.L., Burton, M., 2014. Salt or Sludge? Exploring Preferences for Potable Water Sources. Environ Resource Econ 57, 453-476. https://doi.org/10.1007/s10640-013-9672-9

Gregory, R., Flynn, J., Slovic, P., 2001. Technological stigma. In Flynn, J., Kunreuther, J., Slovic, P. Eds., Risk, media, and stigma, 361-368. Sterling, VA: Earthscan Publication Ltd.

Haddad, B.M., Rozin, P., Nemeroff, C., Slovic, P., 2009. The psychology of water reclamation and reuse. Survey Findings and Research Road Map, WateReuse Found., Alexandria, Va.

Harrison, G.W., List, J.A., 2004. Field Experiments. Journal of Economic Literature 42, 1009-1055. https://doi.org/10.1257/0022051043004577

Hayes, D.J., Fox, J.A., Shogren, J.F., 2002. Experts and activists: how information affects the demand for food irradiation. Food Policy 27, 185-193. https://doi.org/10.1016/S0306-9192(02)00011-8

Hayes, D.J., Shogren, J.F., Shin, S.Y., Kliebenstein, J.B., 1995. Valuing Food Safety in Experimental Auction Markets. Am J Agric Econ 77, 40-53. https://doi.org/10.2307/1243887

Hejmadi, A., Rozin, P., Siegal, M., 2004. Once in contact, always in contact: Contagious essence and conceptions of purification in American and Hindu Indian children. Developmental Psychology 40, 467-476.

Hui, I., Cain, B.E., 2017. Overcoming psychological resistance toward using recycled water in California. Water and Environment Journal n/a-n/a. https://doi.org/10.1111/wej.12285

Hummer, N., Eden, S., 2016. Potable Reuse of Water. The Arroyo. Water Resources Research Center, Tucson, AZ.

Hurlimann, A., 2007. Is recycled water use risky? An urban Australian community’s perspective. The Environmentalist 27, 83-94.

Hurlimann, A., Dolnicar, S., 2016. Public acceptance and perceptions of alternative water sources: a comparative study in nine locations. International Journal of Water Resources Development 32, 650-673. https://doi.org/10.1080/07900627.2016.1143350

Kahneman, D., Tversky, A., 1979. Prospect theory: An analysis of decision under risk. Econometrica 47, 263-292.

Kajale, D.B., Becker, T.C., 2014. Effects of information on young consumers’ willingness to pay for genetically modified food: Experimental auction analysis. Ecology of food and nutrition 53, 292-311.

Kanter, C., Messer, K.D., Kaiser, H.M., 2009. Does Production Labeling Stigmatize Conventional Milk? Am J Agric Econ 91, 1097-1109. https://doi.org/10.1111/j.1467-8276.2009.01317.x

Kecinski, M., Keisner, D.K., Messer, K.D., Schulze, W.D., 2016. Stigma mitigation and the importance of redundant treatments. Journal of Economic Psychology 54, 44-52. 
Kecinski, M., Keisner, D.K., Messer, K.D., Schulze, W.D., 2017. Measuring Stigma: The Behavioral Implications of Disgust. Environ Resource Econ 1-16. https://doi.org/10.1007/s10640-017-0113$\underline{z}$

Kecinski, M., Messer, K.D., 2018a. Mitigating Public Concerns about Recycled Drinking Water: Leveraging the Power of Voting and Communication. Water Resources Research. https://doi.org/10.1029/2017WR022290.

Kecinski, M., Messer, K.D., Peo, A.J., 2018b. When cleaning too much pollution can be a bad thing: A field experiment of consumer demand for oysters. Ecological Economics 146, 686-695.

Lease, H.J., Hatton MacDonald, D., Cox, D.N., 2014. Consumers' acceptance of recycled water in meat products: The influence of tasting, attitudes and values on hedonic and emotional reactions. Food Quality and Preference 37, 35-44. https://doi.org/10.1016/j.foodqual.2014.04.002

Li, T., McCluskey, J. J., Messer, K. D., 2018. Ignorance is bliss? Experimental evidence on wine produced from grapes irrigated with recycled water. Ecological Economics 153, 100-110.

Lusk, J.L., Fox, J.A., 2003. Value elicitation in retail and laboratory environments. Economics Letters 79, 27-34. https://doi.org/10.1016/S0165-1765(02)00284-7

Lusk, J.L., Jamal, M., Kurlander, L., Roucan, M., Taulman, L., 2005. A Meta-Analysis of Genetically Modified Food Valuation Studies. Journal of Agricultural and Resource Economics 30, 28-44.

Lusk, J.L., Shogren, J.F., 2007. Experimental Auctions: Methods and Applications in Economic and Marketing Research. Cambridge University Press.

Lusk, J.L., Schroeder, T.C., Tonsor, G.T., 2014. Distinguishing beliefs from preferences in food choice. Eur Rev Agric Econ 41, 627-655. https://doi.org/10.1093/erae/jbt035

Marin, P., Tal, S., Yeres, J., Ringskog, K.B., 2017. Water Management in Israel: Key Innovations and Lessons Learned for Water Scarce Countries. World Bank.

McKay, J.M., Hurlimann, A., 2003. Attitudes to reclaimed water for domestic use: Part 1. Age. Water 30, 45-49.

McNabb, D.E., 2017. Managing Recycled Water, in: Water Resource Management. Palgrave Macmillan, Cham, pp. 283-306. https://doi.org/10.1007/978-3-319-54816-6_12

McFadden, J.R., Huffman, W.E., 2017. Consumer valuation of information about food safety achieved using biotechnology: Evidence from new potato products. Food Policy 69, 82-96. https://doi.org/10.1016/j.foodpol.2017.03.002

Mekonnen, M.M., Hoekstra, A.Y., 2016. Four billion people facing severe water scarcity. Science Advances 2, e1500323. https://doi.org/10.1126/sciadv.1500323

Menegaki, A.N., Hanley, N., Tsagarakis, K.P., 2007. The social acceptability and valuation of recycled water in Crete: A study of consumers' and farmers’ attitudes. Ecological Economics 62, 7-18. https://doi.org/10.1016/j.ecolecon.2007.01.008

Messer, K.D., Bligh, S., Costanigro, M., Kaiser, H.M., 2015. Process labeling of food: Consumer behavior, the agricultural sector, and policy recommendations. Council for Agricultural Science and Technology (CAST) Issuer Paper 56.

Messer, K.D., Costanigro, M., Kaiser, H.M., 2017. Labeling Food Processes: The Good, the Bad and the Ugly. Appl Econ Perspect Policy 39, 407-427. https://doi.org/10.1093/aepp/ppx028

Messer, K.D., Kaiser, H.M., Payne, C., Wansink, B., 2011. Can generic advertising alleviate consumer concerns over food scares? Applied Economics 43, 1535-1549. https://doi.org/10.1080/00036840802600616

National Groundwater Association, 2017. Brackish Groundwater. Accessed July 5, 2018, at https://www.ngwa.org/docs/default-source/default-document-library/publications/brackishgroundwater.pdf?sfvrsn=5c89617d_2. 
National Research Council, 2012. Water Reuse: Potential for Expanding the Nation's Water Supply Through Reuse of Municipal Wastewater. Washington, DC: The National Academies Press.

Nelson, P., 1970. Information and Consumer Behavior. Journal of Political Economy 78, 311-329. https://doi.org/10.1086/259630

Pham, T.T.N., Ngo, H.H., Guo, W., Dang, H.P.D., Mainali, B., Johnston, A., Listowski, A., 2011. Responses of community to the possible use of recycled water for washing machines: A case study in Sydney, Australia. Resources, Conservation and Recycling 55, 535-540. https://doi.org/10.1016/j.resconrec.2011.01.004

Po, M., Nancarrow, B.E., Kaercher, J.D., 2003. Literature review of factors influencing public perceptions of water reuse.

Po, M., Nancarrow, B.E., Leviston, Z., Porter, N.B., Syme, G.J., Kaercher, J.D., 2005. Predicting Community Behaviour in Relation to Wastewater Reuse : What drives decisions to accept or reject ? Water for a Healthy Country National Research Flagship. CSIRO Land and Water: Perth.

Price, J., Fielding, K.S., Gardner, J., Leviston, Z., Green, M., 2015. Developing effective messages about potable recycled water: The importance of message structure and content. Water Resources Research 51, 2174-2187. https://doi.org/10.1002/2014WR016514

PUB Singapore’s National Water Agency, 2018. NEWater. Accessed July 11, 2018 at https://www.pub.gov.sg/watersupply/fournationaltaps/newater.

Rock, C., Solop, F.I., Gerrity, D., 2012. Survey of statewide public perceptions regarding water reuse in Arizona. Journal of Water Supply: Research and Technology - Aqua 61, 506-517. https://doi.org/10.2166/aqua.2012.070

Ross, V.L., Fielding, K.S., Louis, W.R., 2014. Social trust, risk perceptions and public acceptance of recycled water: Testing a social-psychological model. Journal of Environmental Management 137, 61-68. https://doi.org/10.1016/j.jenvman.2014.01.039

Rozin, P., 2001. Technological stigma: Some perspectives from the study of contagion, in risk, media, and stigma: Understanding public challenges to modern science and technology, Eds. J. Flynn, P. Slovic and H. Kunreuther, 31-40. Sterling, VA: Earthscan Publication Ltd.

Rozin, P., Fallon, A. E., 1987. A perspective on disgust. Psychological Review 94, 23-41.

Rozin, P., Haddad, B., Nemeroff, C., Slovic, P., 2015. Psychological aspects of the rejection of recycled water: Contamination, purification and disgust. Judgment and Decision Making 10, 5063.

Rozin, P., Millman, L., Nemeroff, C., 1986. Operation of the laws of sympathetic magic in disgust and other domains. Journal of personality and social psychology 50, 703-712.

Rozin, P., Nemeroff, C., Horowitz, M., Gordon, B., Voet, W., 1995. The borders of the self: Contamination sensitivity and potency of the body apertures and other body parts. Journal of Research in Personality 29, 318-340.

Savchenko, O., Kecinski, M., Messer, K.D., Li, T., Xu, H., 2018a. Fresh Foods with Recycled Water: A Framed Field Experiment on Consumer Response. Applied Economics \& Statistics Research Report, University of Delaware, RR18-03.

Savchenko, O., Li, T., Kecinski, M., Messer, K.D., 2018b. Does food mitigate consumers’ concerns about crops grown with recycled water? Paper presented at the Agricultural and Applied Economics Association Conference, Washington, DC.

Schmidt, A., Kecinski, M., Li, T., Messer, K. D., Parker, J. J., 2017. Measuring the impacts of different messengers on consumer preferences for products irrigated with recycled water: a field experiment. Paper presented at the Conference on Behavioral and Experimental Agri- 
Environmental Research: Methodological Advancements and Applications to Policy, Shepherdstown, W.V.

Seshadri, B., Bolan, N.S., Kunhikrishnan, A., Chowdhury, S., Thangarajan, R., Chuasavathi, T., 2015. Recycled water irrigation in Australia, in: Environmental Sustainability. Springer, pp. 39-48.

Simpson, J., Stratton, H., 2011. Talking about water: Words and images that enhance understanding. National Water Commission.

Slovic, P., 1987. Perception of risk. Science 236, 280-285.

Swinnen, J., McCluskey, J., Francken, N., 2005. Food safety, the media, and the information market. Agricultural Economics, 32, 175-188.

Townsend, E., 2006. Affective Influences on Risk Perceptions of, and Attitudes Toward, Genetically Modified Food. Journal of Risk Research 9, 125-139.

https://doi.org/10.1080/13669870500085130

Townsend, E., Campbell, S., 2004. Psychological Determinants of Willingness to Taste and Purchase Genetically Modified Food. Risk Analysis 24, 1385-1393. https://doi.org/10.1111/j.02724332.2004.00533.x

Toze, S., 2006. Reuse of effluent water—benefits and risks. Agricultural Water Management, Special Issue on Water Scarcity: Challenges and Opportunities for Crop Science 80, 147-159. https://doi.org/10.1016/j.agwat.2005.07.010

Uhlmann, V., Head, B.W., 2011. Water recycling: Recent history of local government initiatives in South East Queensland. Urban Water Security Research Alliance Technical Report No. 45.

United Nations World Water Assessment Programme, 2016. The United Nations World Water Development Report 2016: Water and Jobs. Paris, UNESCO.

Wester, J., Timpano, K.R., Çek, D., Lieberman, D., Fieldstone, S.C., Broad, K., 2015. Psychological and social factors associated with wastewater reuse emotional discomfort. Journal of Environmental Psychology 42, 16-23. https://doi.org/10.1016/j.jenvp.2015.01.003

World Bank, 2014. Water resources management: Sector results profile. Accessed July 9, 2017, at http://www.worldbank.org/en/results/2013/04/15/water-resources-management-results-profile.

World Resources Institute, 2013. Portion of agricultural production under high or extremely high stress. Accessed on July 13, 2018, at https://www.wri.org/blog/2013/10/one-quarterworld\%E2\%80\%99s-agriculture-grows-highly-water-stressed-areas. 
Figure 1: Consumers’ Mean Preferences for Six Sources of Reclaimed Irrigation Water.

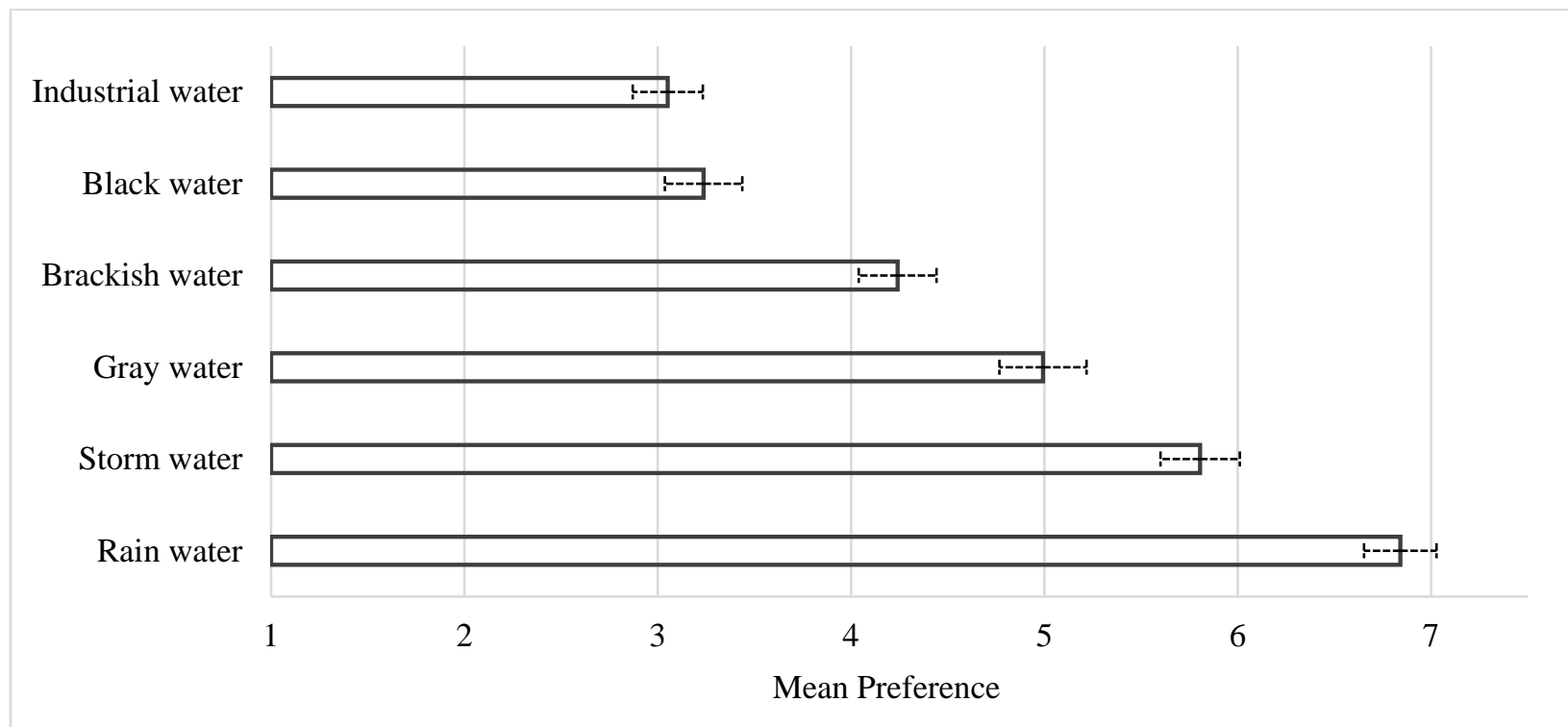

Note: Respondents rated their preferences for the six reclaimed irrigation water sources using Likert scale, where 1 indicated "Dislike" and 9 indicated "Like”. Dashed bars represent 95\% confidence intervals. 
Figure 2: Key Drivers of Consumer Acceptance and Rejection of Reclaimed Water.

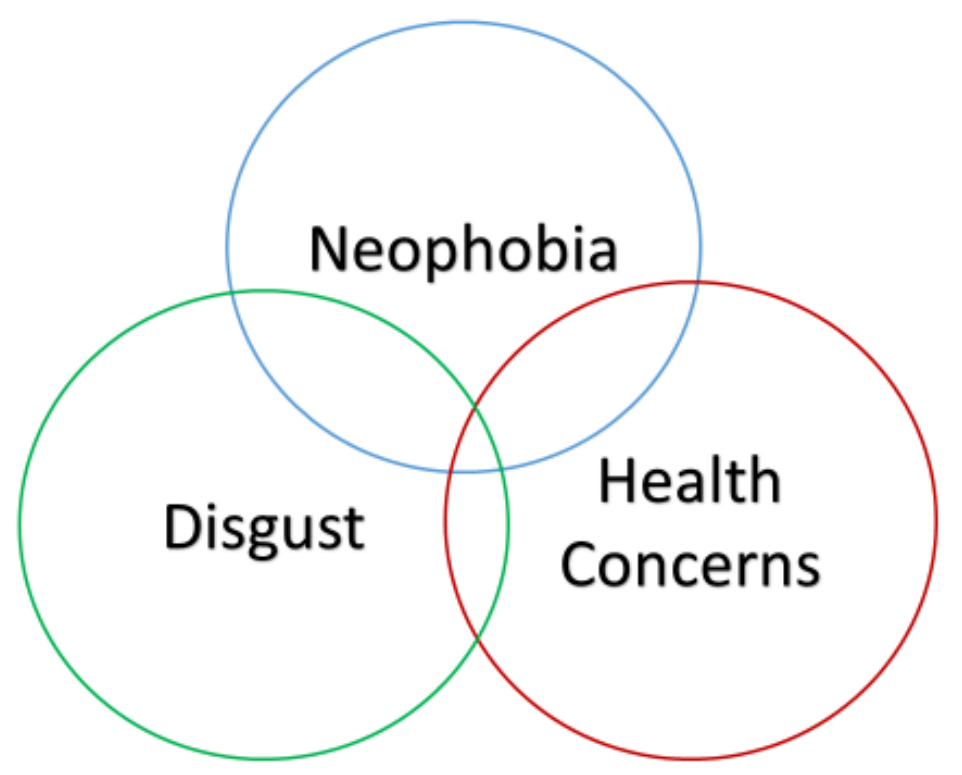


Table 1: Summary Statistics of Socio-demographic and Behavioral Characteristics

\begin{tabular}{lc}
\hline Number of respondents & 540 \\
Average age & 38.8 \\
\hline & Percentage of respondents (\%) \\
\cline { 2 - 2 } Female & 59.9 \\
Children under 18 in the household & 30.3 \\
Education & \\
No high school degree & 2.8 \\
High school graduate & 11.1 \\
Some college & 18.6 \\
Associate degree & 7.7 \\
Bachelor degree & 33.3 \\
Graduate degree/Professional degree & 26.5 \\
Household Income & \\
Less than \$10,000 & 9.8 \\
\$10,000-\$14,999 & 4.0 \\
\$15,000-\$24,999 & 12.2 \\
\$25,000-\$34,999 & 8.5 \\
\$35,000-\$49,999 & 13.2 \\
\$50,000-\$74,999 & 19.3 \\
\$75,000-\$99,999 & 9.9 \\
\$100,000-\$149,999 & 13.8 \\
\$150,000-\$199,999 & 6.1 \\
\$200,000-\$249,999 & 1.8 \\
\$250,000 and above & 1.4 \\
Political Affiliation & \\
Liberal & 37.1 \\
Conservative & 19.2 \\
Moderate & 37.0 \\
Other & 6.8 \\
Prefer Local Food & 64.5 \\
Primary Shopper & 72.9 \\
Grow Own Food & 28.3 \\
Heard of Reclaimed Water & 68.4 \\
Organic foods comprise at least half of food consumption & 40.0 \\
Drinking Water Preference & \\
Bottled & 42.5 \\
Filtered Tap & 35.4 \\
Tap & 2.4 \\
Other & \\
\hline
\end{tabular}


Table 2: Responses Regarding Participants' Concerns Related to Water

\begin{tabular}{|c|c|c|}
\hline & Mean & Median \\
\hline \multicolumn{3}{|c|}{ Concern for water in the following periods (1-9 scale) } \\
\hline Now & 5.70 & 6 \\
\hline In the next 10 years & 6.59 & 7 \\
\hline More than 50 years & 7.21 & 8 \\
\hline \multicolumn{3}{|c|}{ Attitude to reclaimed source of irrigation water (1-9 scale) } \\
\hline Grey water & 4.99 & 5 \\
\hline Black water & 3.24 & 3 \\
\hline Brackish water & 4.24 & 5 \\
\hline Industrial water & 3.05 & 3 \\
\hline Rainwater & 6.84 & 7 \\
\hline \multirow[t]{2}{*}{ Stormwater } & 5.81 & 6 \\
\hline & \multicolumn{2}{|c|}{ Percent } \\
\hline \multicolumn{3}{|c|}{ Concern for water in the following areas (yes/no) } \\
\hline In your community & \multicolumn{2}{|c|}{70.19} \\
\hline In your state & \multicolumn{2}{|c|}{71.48} \\
\hline In the United States & \multicolumn{2}{|c|}{77.96} \\
\hline Worldwide & \multicolumn{2}{|c|}{89.26} \\
\hline
\end{tabular}


Table 3: Consumers’ Preferences for Reclaimed Irrigation Water.

\begin{tabular}{|c|c|c|c|}
\hline & & Coeff. & S.E. \\
\hline \multirow{5}{*}{ Irrigation Water Type } & Gray & $-1.848 * * *$ & $(0.112)$ \\
\hline & Brackish & $-2.519 * * *$ & $(0.103)$ \\
\hline & Industrial & $-3.680 * * *$ & $(0.134)$ \\
\hline & Stormwater & $-1.034 * * *$ & $(0.087)$ \\
\hline & Black & $-3.548 * * *$ & $(0.124)$ \\
\hline \multirow{5}{*}{ Demographics } & Age & -0.004 & $(0.005)$ \\
\hline & Female & $-0.522 * * *$ & $(0.163)$ \\
\hline & Education & 0.245 & (0.171) \\
\hline & Income & 0.056 & $(0.035)$ \\
\hline & Children & -0.170 & $(0.178)$ \\
\hline \multirow{5}{*}{ Behavioral Attributes } & Primary & 0.176 & $(0.179)$ \\
\hline & Heard & $0.533^{* * *}$ & $(0.173)$ \\
\hline & Organic & -0.090 & $(0.178)$ \\
\hline & Prefer Local Food & 0.199 & $(0.171)$ \\
\hline & Grow Own Food & 0.188 & $(0.165)$ \\
\hline \multirow{3}{*}{ Political Affiliation } & Liberal & 0.342 & (0.309) \\
\hline & Moderate & 0.356 & $(0.296)$ \\
\hline & Conservative & -0.241 & $(0.340)$ \\
\hline \multirow{6}{*}{ Drinking Water Preference } & Filtered Tap & 0.0729 & (0.399) \\
\hline & Tap & 0.448 & $(0.414)$ \\
\hline & Bottled & -0.282 & $(0.407)$ \\
\hline & Location Fixed Effect & $\mathrm{Y}$ & - \\
\hline & Observations & 3,240 & 3,240 \\
\hline & Number of Subjects & 540 & 540 \\
\hline
\end{tabular}

Note: Robust standard errors are shown in parentheses. ${ }^{* *}$ Significant at $1 \%$ level. ${ }^{* *}$ Significant at $5 \%$ level. Each of the 540 survey respondents rated their preferences for six different types of reclaimed water sources water, yielding a total of 3,240 observations. 
Table 4: Consumers' Preferences for Six Sources of Reclaimed Irrigation Water.

\begin{tabular}{|c|c|c|c|c|c|c|}
\hline & Black water & Gray water & Brackish water & Industrial water & Rain water & Storm water \\
\hline \multirow[t]{2}{*}{ Age } & -0.00266 & $0.0135 * *$ & -0.00816 & -0.00540 & -0.000467 & $-0.0133^{* *}$ \\
\hline & $(0.00604)$ & $(0.00571)$ & (0.00619) & (0.00589) & (0.00598) & (0.00589) \\
\hline \multirow[t]{2}{*}{ Female } & $-0.501 * * *$ & -0.222 & $-0.541 * * *$ & -0.0552 & $-0.413^{* *}$ & $-0.442 * * *$ \\
\hline & $(0.178)$ & $(0.175)$ & $(0.172)$ & $(0.173)$ & $(0.176)$ & $(0.166)$ \\
\hline \multirow[t]{2}{*}{ Education } & 0.00470 & 0.225 & 0.195 & -0.294 & $0.680 * * *$ & 0.0192 \\
\hline & $(0.188)$ & $(0.175)$ & $(0.179)$ & $(0.190)$ & $(0.181)$ & $(0.181)$ \\
\hline \multirow[t]{2}{*}{ Income } & 0.0475 & 0.0218 & 0.0707 & 0.0254 & 0.0595 & 0.00551 \\
\hline & $(0.0379)$ & $(0.0359)$ & $(0.0375)$ & $(0.0364)$ & $(0.0379)$ & $(0.0362)$ \\
\hline \multirow[t]{2}{*}{ Children } & 0.0693 & -0.272 & -0.169 & 0.0829 & -0.268 & -0.332 \\
\hline & $(0.173)$ & $(0.169)$ & $(0.177)$ & $(0.185)$ & $(0.173)$ & $(0.171)$ \\
\hline \multirow[t]{2}{*}{ Primary } & -0.0739 & 0.271 & 0.167 & 0.00101 & 0.275 & 0.215 \\
\hline & $(0.193)$ & $(0.175)$ & $(0.181)$ & $(0.194)$ & $(0.192)$ & $(0.188)$ \\
\hline \multirow[t]{2}{*}{ Heard } & $0.441 * *$ & $0.621 * * *$ & 0.337 & -0.0173 & $0.651 * * *$ & $0.385 * *$ \\
\hline & $(0.185)$ & $(0.175)$ & $(0.176)$ & $(0.192)$ & $(0.182)$ & $(0.165)$ \\
\hline \multirow[t]{2}{*}{ Organic } & 0.114 & -0.0746 & 0.0658 & 0.130 & -0.262 & $-0.360 * *$ \\
\hline & $(0.193)$ & $(0.186)$ & $(0.182)$ & $(0.191)$ & $(0.178)$ & $(0.183)$ \\
\hline \multirow[t]{2}{*}{ Prefer Local Food } & -0.0704 & 0.304 & 0.225 & -0.199 & 0.233 & 0.123 \\
\hline & $(0.173)$ & $(0.162)$ & $(0.173)$ & $(0.175)$ & $(0.176)$ & $(0.167)$ \\
\hline \multirow[t]{2}{*}{ Grow Own Food } & -0.00795 & 0.171 & -0.0158 & $-0.374^{* *}$ & $0.621 * * *$ & $0.568 * * *$ \\
\hline & $(0.185)$ & $(0.179)$ & $(0.181)$ & $(0.180)$ & $(0.193)$ & $(0.196)$ \\
\hline \multirow[t]{2}{*}{ Liberal } & 0.348 & $0.864 * *$ & 0.653 & 0.292 & -0.0258 & 0.0355 \\
\hline & $(0.376)$ & $(0.370)$ & $(0.347)$ & $(0.338)$ & $(0.303)$ & $(0.301)$ \\
\hline \multirow[t]{2}{*}{ Moderate } & 0.275 & 0.598 & 0.515 & 0.423 & -0.180 & 0.199 \\
\hline & $(0.365)$ & $(0.357)$ & $(0.342)$ & (0.319) & $(0.290)$ & $(0.287)$ \\
\hline \multirow[t]{2}{*}{ Conservative } & -0.270 & 0.407 & 0.256 & -0.0361 & -0.272 & -0.342 \\
\hline & $(0.392)$ & $(0.397)$ & $(0.363)$ & $(0.353)$ & $(0.337)$ & $(0.326)$ \\
\hline \multirow[t]{2}{*}{ Filtered Tар } & 0.412 & 0.0300 & -0.0300 & 0.282 & -0.271 & -0.365 \\
\hline & $(0.574)$ & $(0.456)$ & $(0.508)$ & $(0.470)$ & $(0.662)$ & $(0.509)$ \\
\hline \multirow[t]{2}{*}{ Tap } & 0.538 & 0.507 & 0.102 & 0.692 & 0.0611 & -0.349 \\
\hline & (0.599) & $(0.470)$ & $(0.528)$ & $(0.486)$ & $(0.674)$ & $(0.532)$ \\
\hline \multirow[t]{2}{*}{ Bottle } & 0.321 & -0.265 & -0.259 & 0.241 & -0.543 & -0.739 \\
\hline & $(0.574)$ & $(0.456)$ & $(0.511)$ & $(0.466)$ & $(0.669)$ & $(0.515)$ \\
\hline $\begin{array}{l}\text { Location Fixed } \\
\text { Effect }\end{array}$ & $\mathrm{Y}$ & $\mathrm{Y}$ & $\mathrm{Y}$ & $\mathrm{Y}$ & $\mathrm{Y}$ & $\mathrm{Y}$ \\
\hline Observations & 540 & 540 & 540 & 540 & 540 & 540 \\
\hline
\end{tabular}

Note: *** Significant at $1 \%$ level. **Significant at $5 \%$ level. 


\section{Appendix A: Survey}

1. What is your age?

2. What is your gender?

Male

Female

Other (please specify)

3. Which one of the following categories best describes your employment status:

Government

Education

Business

Agriculture

Student

Other (please specify)

4. Are you:

Politically liberal

Politically moderate

Politically conservative

Other (please specify)

5. Which category best describes your household income (before taxes) in 2015?

Less than $\$ 10,000$

$\$ 10,000-\$ 14,999$

$\$ 15,000-\$ 24,999$

$\$ 25,000-\$ 34,999$

$\$ 35,000-\$ 49,999$

$\$ 50,000-\$ 74,999$

$\$ 75,000-\$ 99,999$

$\$ 100,000-\$ 149,999$

$\$ 150,000-\$ 199,999$

$\$ 200,000-\$ 249,999$

$\$ 250,000$ and above

6. What is the highest level of education that you have completed?

Grade school

Some high school

High school graduate

Some college credit

Associate degree

Bachelor's degree

Graduate degree/Professional

7. Do you have a child/children under the age of 18 years old in your household? Yes/No

8. How often do you consume the following foods: 
Fresh Grapes: times per month

Grape Juice: times per month

Raisins: times per month

Fresh Olives: times per month

Olive Oil: times per month

Dried Olives: times per month

9. Are you the primary shopper in your household?

Yes/No

10. What is the percentage of organic foods in your overall foods consumption?

Non-Organic (50\%) Organic (50\%)

11. Do you grow your own food?

Yes/No

12. Which do you prefer?

Local Food

Non-Local Food

Don't care

13. How important are the following foods characteristics to you?

Price:

Organic:

Non-GMO:

Appearance:

Smell:

Growing Location:

Brand:
Not Important (1); Very Important (9)

Not Important (1); Very Important (9)

Not Important (1); Very Important (9)

Not Important (1); Very Important (9)

Not Important (1); Very Important (9)

Not Important (1); Very Important (9)

Not Important (1); Very Important (9)

14. How do you drink your water?

Bottled Water

Filtered Tap Water

Tap Water

Other (please specify)

15. How concerned are you about water availability in the following areas?

Your Community: $\quad$ Not At All (1); Very Concerned (9)

Your State: $\quad$ Not At All (1); Very Concerned (9)

United States: $\quad$ Not At All (1); Very Concerned (9)

Worldwide: $\quad$ Not At All (1); Very Concerned (9)

16. How concerned are you about water availability in the following time periods?
Present:
Not At All (1); Very Concerned (9)
Next 10 Years:
Not At All (1); Very Concerned (9)
Next 30 Years:
Not At All (1); Very Concerned (9)
Further Future:
Not At All (1); Very Concerned (9)

17. Have you heard of recycled/reuse/reclaimed water before?

Yes/No 
18. How do you feel about these different types of non-traditional waters for irrigation?

Grey Water: $\quad$ Dislike (1); Like (9)

It generally refers to the wastewater generated from household uses like bathing and washing clothes.

Black Water: $\quad$ Dislike (1); Like (9)

Also described as Brown Water. It generally refers to the wastewater generated from toilets.

Brackish Water: $\quad$ Dislike (1); Like (9)

It is typically defined as distastefully salty but less saline than seawater (between 1,000 to 10,000

ppm [parts per million] in total dissolved solids [TDS]). In addition to certain surface water settings such as estuaries, brackish water can be found in aquifers.

Industrial Water: $\quad$ Dislike (1); Like (9)

It generally means process and non-process wastewater from manufacturing, commercial, mining, and silvicultural (forestry) facilities or activities, including the runoff and leachate from areas that receive pollutants associated with industrial or commercial storage, handling or processing, and all other wastewater not otherwise defined as domestic wastewater.

Rain Water: $\quad$ Dislike (1); Like (9)

Generally, the term rain water refers to water coming from rooftops and other aboveground surfaces.

Storm Water: $\quad$ Dislike (1); Like (9)

Generally, the term storm water refers to rainwater collected from non-roof surfaces, such as parking lots, hardscapes, and landscapes surrounding urban buildings. 


\section{Appendix B: Variable Definitions}

\begin{tabular}{ll}
\hline Variable & \multicolumn{1}{c}{ Definition } \\
\hline Age & Participants age \\
Female & Equals 1 if female \\
Education & Equals 1 if Bachelor or graduate degree \\
Income & Categorical (1-lowest, 11- highest) \\
Children & Equals 1 if children under 18 present in the household, \\
Primary & Equals 1 if participant is a primary shopper \\
Heard & Equals 1 if participant hear about reclaimed water before \\
Organic & Equals 1 if more than 50\% of total food consumption is organic \\
Local & Equals 1 if prefer local \\
Grow Food & Equals 1 if participant grows own food \\
Liberal & Equals 1 if liberal political affiliation \\
Moderate & Equals 1 if moderate political affiliation \\
Conservative & Equals 1 if conservative political affiliation \\
Filtered Tap & Equals 1 if prefer filtered tap drinking water \\
Tap & Equals 1 if prefer tap drinking water \\
Bottled & Equals 1 if prefer bottled drinking water \\
\hline
\end{tabular}




\section{The Department of Applied Economics and Statistics \\ College of Agriculture and Natural Resources \\ University of Delaware}

The Department of Applied Economics and Statistics carries on an extensive and coordinated program of teaching, organized research, and public service in a wide variety of the following professional subject matter areas:

\section{Subject Matter Areas}

Agricultural Policy

Food and Agribusiness Management and Marketing

Natural Resource Management

Rural and Community Development
Environmental and Resource Economics International Agricultural Trade

Price and Demand Analysis

Statistical Analysis and Research Methods

The department's research in these areas is part of the organized research program of the Delaware Agricultural Experiment Station, College of Agriculture and Natural Resources. Much of the research is in cooperation with industry partners, the USDA, and other State and Federal agencies. The combination of teaching, research, and service provides an efficient, effective, and productive use of resources invested in higher education and service to the public. Emphasis in research is on solving practical problems important to various segments of the economy.

The mission and goals of our department are to provide quality education to undergraduate and graduate students, foster free exchange of ideas, and engage in scholarly and outreach activities that generate new knowledge capital that could help inform policy and business decisions in the public and private sectors of the society. APEC has a strong record and tradition of productive programs and personnel who are engaged in innovative teaching, cutting-edge social science research, and public service in a wide variety of professional areas. The areas of expertise include: agricultural policy; environmental and resource economics; food and agribusiness marketing and management; international agricultural trade; natural resource management; operations research and decision analysis; rural and community development; and statistical analysis and research methods. 
APEC Research

Reports are published

by the Department of

Applied Economics

and Statistics, College

of Agriculture and

Natural Resources of

the University of

Delaware.

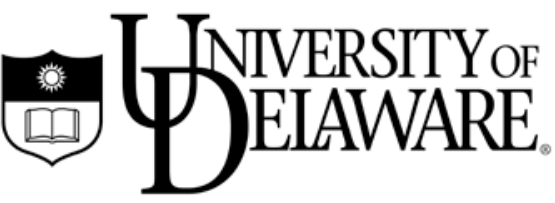

